\title{
Susceptibility of Some Selected Nitte Municipal Wastewater Sources to Trace Metals Pollution
}

\author{
Samson 0. Ojoawo*, Gaddale Udayakumar \\ Department of Civil Engineering, NMAM Institute of Technology, Udupi, India \\ Email: soojoawo@lautech.edu.ng
}

Received 11 May 2014; revised 12 June 2014; accepted 26 June 2014

Copyright (C) 2014 by authors and Scientific Research Publishing Inc.

This work is licensed under the Creative Commons Attribution International License (CC BY).

http://creativecommons.org/licenses/by/4.0/

(c) (i) Open Access

\section{Abstract}

The negative impacts of pollution due to trace metals in wastewater on aquatic ecosystem and related organisms in water bodies are on the increase. This paper deals with the investigation on the pollution indices of trace metals in selected wastewater samples of Nitte Town, Udupi District, Karnataka State, India. Twelve wastewater samples were obtained from Students Hostels, Auto-Service Workshop Station, Foundry, Laundry, Landfill Leachate and Wastewater Treatment Plant Inlet. The measured heavy metals in the samples include: Copper (Cu), Lead (Pb), Magnesium (Mg), Chromium (Cr), Nickel (Ni), Zinc (Zn), Manganese (Mn) and Cadmium (Cd), using the air-acetylene-operated Flame Atomic Absorption Spectrometer (FAAS), Avanta GM model. The results were all compared with the EPA Effluent Standards. Findings revealed that all samples recorded dwindling levels of trace metals pollution when compared with the Standards. The heaviest concentration occurred in Cd with as high as $1856.4 \mathrm{ppm}$ as found in the Stale Landfill Leachate sample, while the least contaminating metal in the samples is Manganese which was detected in only Aerated Wastewater Treatment Plant sample (2.3 ppm). This study is therefore recommending Electro-coagulation treatment method for trace metals with high concentration levels like Cd, $\mathrm{Pb}, \mathrm{Mg}$ and $\mathrm{Cu}$, while those with lesser concentration such as $\mathrm{Mn}, \mathrm{Cr}, \mathrm{Ni}$ and $\mathrm{Zn}$ in the samples are suggested to be treated with chemical precipitation method.

\section{Keywords}

Trace Metals, Municipal Wastewater, Pollution, Nitte

\section{Introduction}

The term "trace metal" includes a number of chemical elements that occur in natural systems in small concen-

*Corresponding author.

How to cite this paper: Ojoawo, S.O. and Udayakumar, G. (2014) Susceptibility of Some selected Nitte Municipal Wastewater Sources to Trace Metals Pollution. Computational Water, Energy, and Environmental Engineering, 3, 93-101.

http://dx.doi.org/10.4236/cweee.2014.33010 
trations. Boron (B), cadmium (Cd), chromium (Cr), copper $(\mathrm{Cu})$, lead $(\mathrm{Pb})$, mercury $(\mathrm{Hg})$, nickel $(\mathrm{Ni})$, and zinc (Zn), widely used in industrial processing and in manufacturing of consumer goods, are the most common trace metals in municipal wastewaters [1]. In another report [2] expanded the trace metal's list to include arsenic (As), silver (Ag), and iron (Fe). It has been noted that the significant part of the anthropogenic emissions of heavy metals ends up in wastewater [3]. Most of the industrial sources of trace metals include surface treatment processes with elements such as $\mathrm{Cd}, \mathrm{Pb}, \mathrm{Mn}, \mathrm{Cu}, \mathrm{Zn}, \mathrm{Cr}, \mathrm{Hg}$, As, $\mathrm{Fe}$ and $\mathrm{Ni}$, as well as industrial products that, at the end of their life, are discharged in wastewater. In urban centers, volume of sewage water increases through household effluents, drainage water, business effluents (e.g., car washes, dental uses, other enterprises, etc.), atmospheric deposition, and traffic related emissions (vehicle exhaust, brake linings, tires, asphalt wear, gasoline/oil leakage, etc.) transported with storm water into the sewerage system [4] [5].

According to the [6] European Commission (2002), most common sources of heavy metals to waste water are Mining and extraction - by mining and extraction a part of the heavy metals will end up in tailings and other waste products. A significant part of the turn-over of the four heavy metals with mining waste actually concerns the presence of the heavy metals in waste from extraction of other metals like zinc, copper and nickel; Primary smelting and processing - a minor part of the heavy metals will end up in waste from the further processing of the metals; Use phase-a small part of the heavy metals may be lost from the products during use by corrosion and wear. The lost material may be discharged to the environment or end up in solid waste either as dust or indirectly via sewage sludge; Waste disposal — the main part of the heavy metals will still be present when the discarded products are disposed of. The heavy metals will either be collected for recycling or disposed of to municipal solid waste incinerators (MSWI) or landfills or liquid waste. A minor part will be disposed of as chemical waste and recycled or land-filled via chemical waste treatment, volcanic eruptions, fossil fuel combustion, agriculture, erosions, and metallurgical industries.

It has been established that many of the trace metals are necessary for human health. Iron, copper, zinc, nickel and other trace elements are needed for proper functioning of biological systems, but their over-exposure can lead to adverse health consequences [7]-[9]. For instance, child lead poisoning causes delayed brain development or acute brain problems and also affects the safety of aquatic organisms at a concentration of $0.16 \mathrm{mg} / \mathrm{l}$ [10]. Excessive chromium in humans causes mouth ulcers, nosebleeds, kidney disease, low white blood cell counts and a variety of cancers [11]. Zinc is found naturally in rocks, air, water and soil. The average human body system contains about $3 \mathrm{~g}$ of zinc, the highest levels being in muscles, liver, kidneys, bones and prostate. The recommended daily zinc intake is $12 \mathrm{mg} /$ day for adult women and $15 \mathrm{mg} /$ day for adult men. Uptake of too much of the trace element can lead to toxicity, such as that, high doses of zinc can lead to gastro-intestinal disorders. On the other hand, deficiencies of some of these trace elements may equally lead to a number of disorders [12]. When uptake of zinc, for example is too low, deficiency occurs in form of reduced sense of taste and smell, skin disorders, mental lethargy and reduced fertility.

In order to determine the heavy trace metals, there are many inorganic techniques [13] such as: Flame Atomic Absorption Spectrometry (FAAS), Graphite Furnace (or Electrothermal) Atomic Absorption Spectrometry (GFAAS or ETAAS), Inductively Coupled Plasma Optical Emission Spectrometry (ICP-OES), Inductively Coupled Plasma Mass Spectrometry (ICP-MS), Anodic Stripping, and Laser Induced Breakdown Spectroscopy (LIBS), among others. The main factors influencing the choice of technique include: the number of elements to be determined, expected concentration range of analytes, and the number of samples to be run.

The main objective of this paper is to investigate the levels of concentrations of selected trace metals in the municipal waste water of Nitte Community with a view to determining their pollution status.

\section{Methodology}

\subsection{The Study Area}

The study area is Nitte, a town in Karkal Taluk in Udupi District of Karnataka State, India. The sampling locations are on the Campus of the NMAM Institute of Technology: an Auto-workshop, a Laundry, a Foundry, Landfill leachate, and a Waste Treatment Plant, all within the neighbourhood of Nitte Settlement. It is located $30 \mathrm{~km}$ towards East from District head quarters Udupi, $10 \mathrm{~km}$ from Karkal and $336 \mathrm{~km}$ from the State capital Bangalore. The study area's elevation/altitude is 20 meters above mean sea level. Udupi district experiences a typical maritime climate with an average temperature of $26.5^{\circ} \mathrm{C}$. The district gets highest annual rainfall in Karnataka state, about $4000 \mathrm{~mm}$ [14] (Ojoawo and Udayakumar, 2014). The study area and layout plan of NMAMIT campus are 
presented in Figure 1 and Figure 2 respectively.

\subsection{Sampling}

Sampling was done using Standard Methods. Twelve concordant samples were collected and analyzed from the wastewater emanating in the study area. In addition to this, a blank sample was prepared for calibration in each measurement process while five Standard samples of known concentrations were employed in the measurement, making a total of eighteen being analyzed. Table 1 gives the details of the Samples and their representations.

\subsection{Laboratory Analysis}

Samples were analyzed using the FAAS, Avanta GM model, of the Department of Bio-Technology, NMAM Institute of Technology, Nitte as shown in Figure 3 and Figure 4. The FAAS's main specifications include: sensitivity of up to ppb level; two channels (independent or simultaneous); wavelength range of between $180 \mathrm{~nm}$ and $900 \mathrm{~nm}$; and probe of teflon tubing-1.6 mm OD (0.8 mm ID).

The equipment was calibrated using the prescribed procedures. The five Standard samples of pre-determined concentrations on each of the element were used in the correlations of the absorbance with the concentration. Eight trace elements were measured in each of the samples; these include $\mathrm{Cu}, \mathrm{Mg}, \mathrm{Pb}, \mathrm{Cr}, \mathrm{Ni}, \mathrm{Zn}, \mathrm{Mn}$, and $\mathrm{Cd}$. The flame used in the analysis was air-acetylene. The temperature formed in the air-acetylene flame was around $2300^{\circ} \mathrm{C}$. The FAAS technique made use of the fact that neutral or ground state atoms of an element can absorb electromagnetic radiation over a series of very narrow, sharply defined wavelengths. The sample in solution was aspirated as a fine mist into a flame where it was converted into atomic vapor. Most of the atoms remained in the ground state and were therefore capable of absorbing radiation of a suitable wavelength. This discrete radiation was supplied by a hollow cathode lamp, which a sharp line source consisting of a cathode was containing the element to be determined along with the tungsten anode. The line characteristic of the element were emitted by the hollow cathode and passed through the flame where they were absorbed by the atomic vapor, since only the test element can absorb this radiation, the method became specific.

The block diagram of the FAAS or GFAAS is shown in Figure 5 while the details of samples and instrumentations are in Table 2. The samples were all introduced manually and two replicate samples were measured for each of the elements.

\section{Results and Discussion}

The results of concentration levels of each trace element in the samples compared with the Environmental Protection Agency (EPA) Effluent Standards of 1998 are presented in Table 3.

From the table it is generally observed that for all the measured trace metals in the sewage samples there are dwindling levels of pollution recorded when values are compared with the EPA Standards. Magnesium could however not be compared due to the unavailability of its permissible recommended value on the consulted EPA Standard. The trends of pollution levels in the samples, as compared with EPA standards, are as displayed in Figures 6-12.

The results of the concentration levels of each of the trace elements are discussed below:

Copper $(\mathrm{Cu}$ - - It is observed that the Stale Landfill Leachate has the highest concentration pollution of 26.7 compared with the recommended $3.00 \mathrm{ppm}$. There are also traces of Cu pollution in Samples from the Wastewater Treatment Plant Inlet (4.6 ppm), Central Workshop Wastewater (3.8 ppm) and the Foundry Settled Sludge Effluent (3.1 ppm). The Cu pollution is found to be marginal in the Postgraduate Girls' Hostel Wastewater. All the rest samples however did not constitute $\mathrm{Cu}$ pollution as far as the Standards are concerned.

Lead $(\mathrm{Pb}$ ) - Pollution above the Standard is found in practically all the samples except the Female Hostel Kitchen Greywater and in the Foundary Settled Sludge Effluent, due to the preliminary treatment it has undergone. Its concentration is low at the domestic sources like the Boys’ and Postgraduate Girls’ Hostel Wastewater, and also in the Commercial Laundry Wastewater. The highest pollution index of $\mathrm{Pb}$ is from Fresh Landfill Leachate. The Auto-Service Wastewater, Wastewater Treatment Plant's Inlet, and the Aerated Wastewater at the Treatment Plant have fairly $\mathrm{Pb}$ pollution levels.

Magnesium (Mg)-Its concentration is at its peak in the Stale Landfill Leachate sample (821.6 ppm), and equally higher in the Fresh Landfill Leachate (417.4 ppm). Mg is detected in all the tested samples with its least 


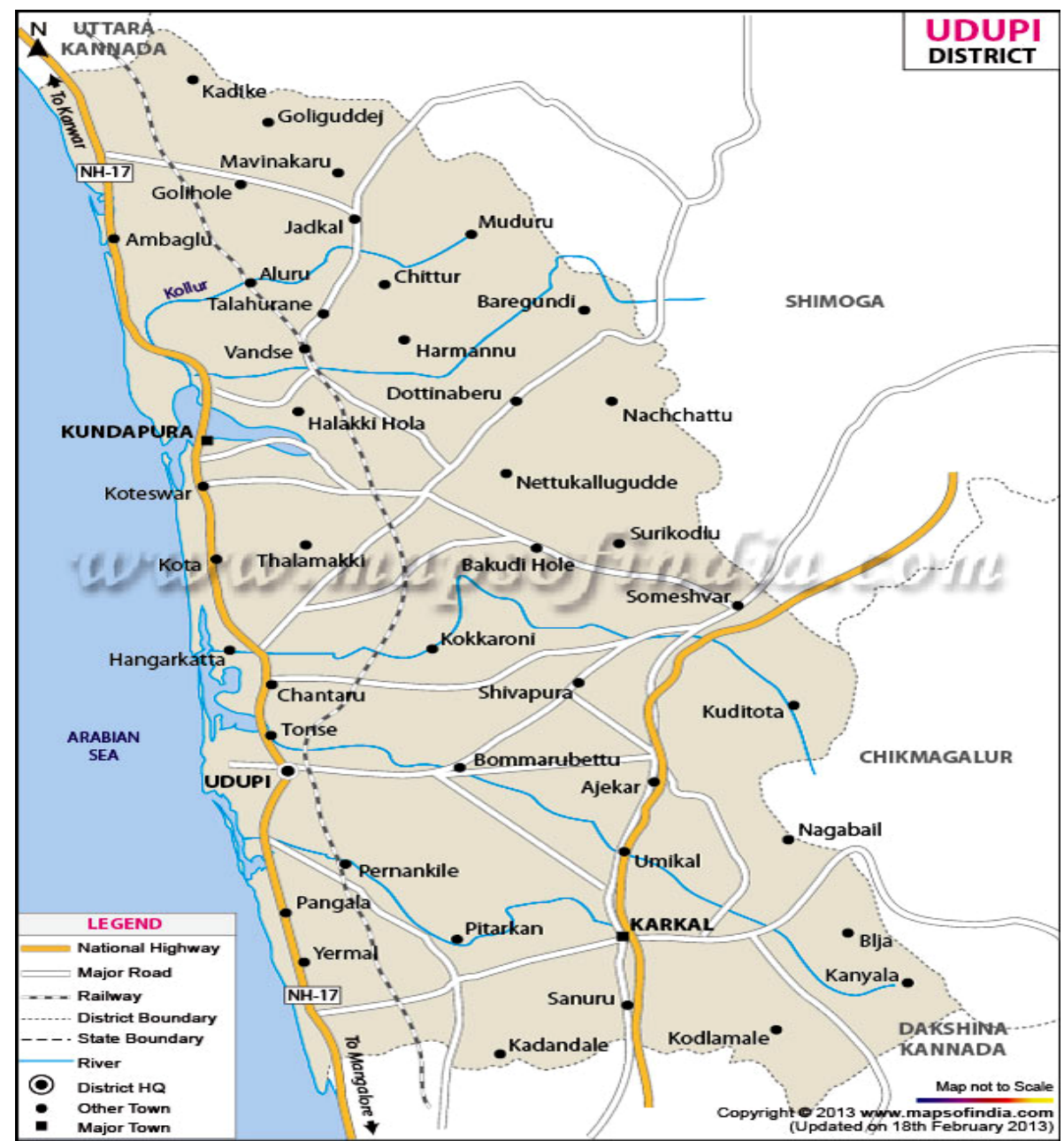

Figure 1. Map of udupi district of Karnataka state.

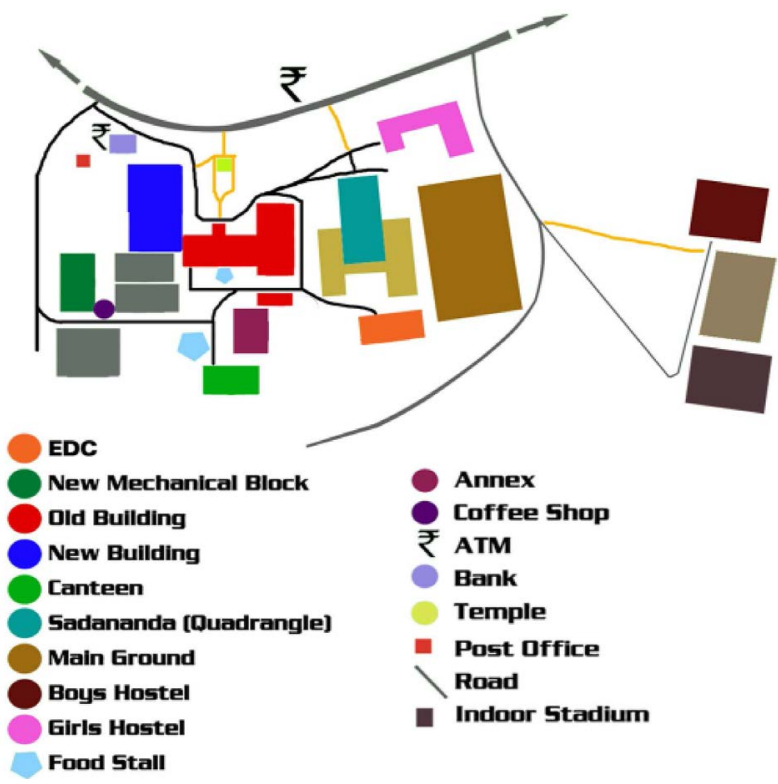

Figure 2. The layout plan of Nmamit campus. 


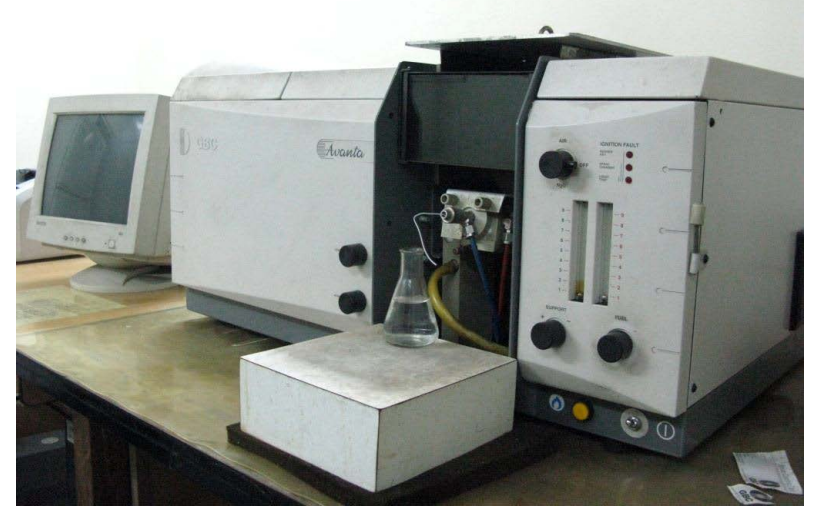

Figure 3. The Avanta GM FAAS used for the analysis.

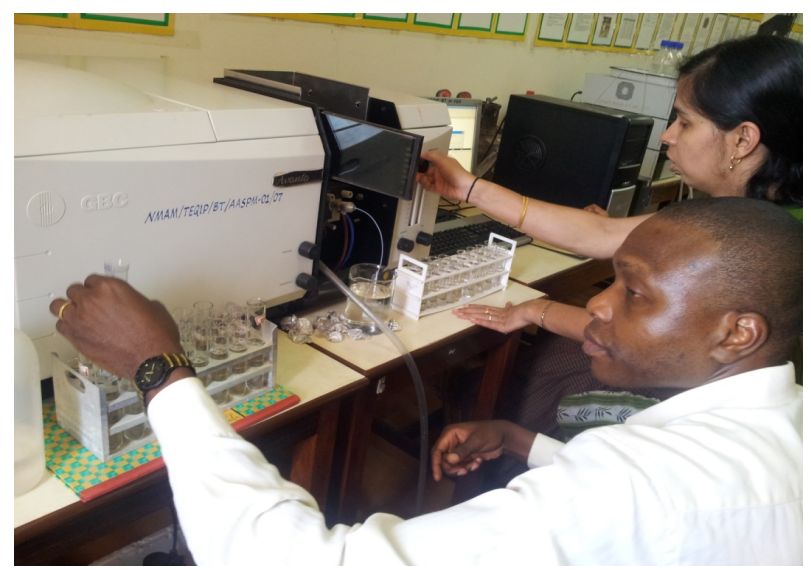

Figure 4. Determination of the trace elements in wastewater samples using the FAAS.

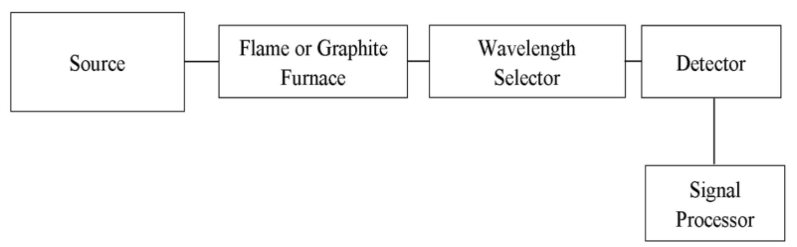

Figure 5. The block diagram of FAAS or GFAAS.

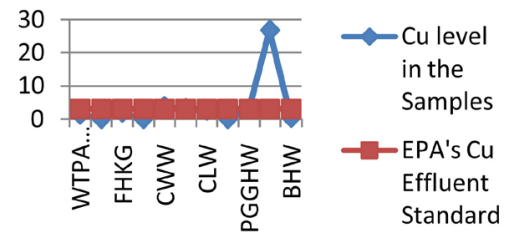

Figure 6. Comparison of $\mathrm{Cu}$ level in the samples with the EPA Effluent Standards.

value being in the Female Hostel Kitchen Greywater. The rest samples are all permeated with Mg in one way or the other.

Chromium (Cr) - The detection of Cr is only in three samples viz: Foundry Settled Sludge Effluent, Central 


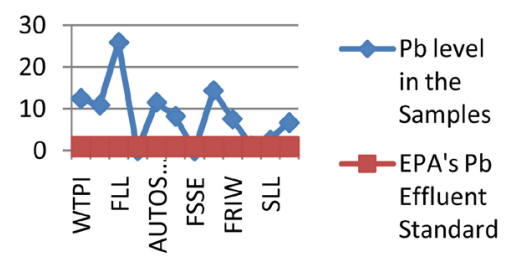

Figure 7. Comparison of $\mathrm{Pb}$ level in the samples with the EPA Effluent Standards.

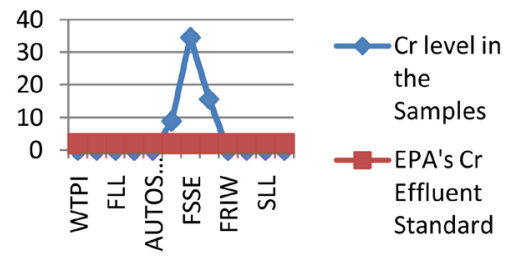

Figure 8. Comparison of $\mathrm{Cr}$ level in the samples with the EPA Effluent Standards.

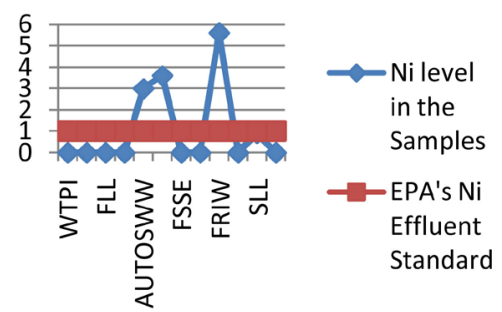

Figure 9. Comparison of Ni level in the samples with the EPA Effluent Standards.

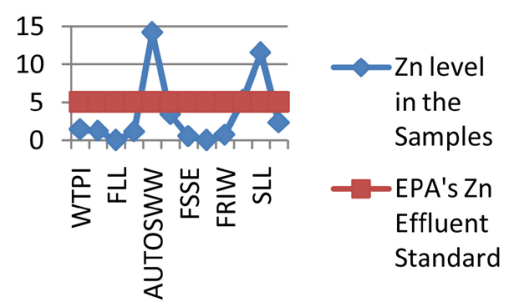

Figure 10. Comparison of $\mathrm{Zn}$ level in the samples with the EPA Effluent Standards.

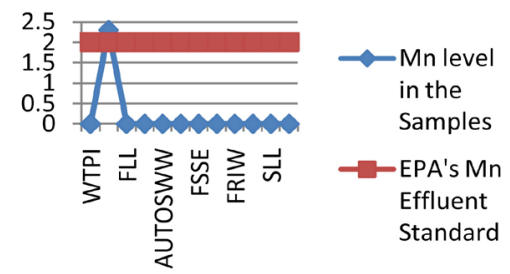

Figure 11. Comparison of Mn level in the samples with the EPA Effluent Standards.

Workshop Wastewater and in the Commercial Laundry Wastewater. Its presence constitutes pollution in the 3 samples when compared with the Standards. The highest concentration of 34.9 ppm is observed in the Foundry works perhaps from the cooling water effluent discharged into the drains.

Nickel (Ni) - This is found in excess of the 1 ppm Standards in the Foundry Raw Inlet Wastewater, 5.6 ppm 


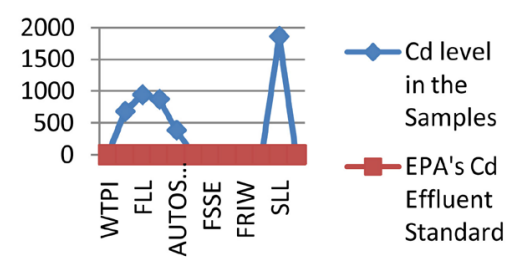

Figure 12. Comparison of Cd level in the samples with the EPA Effluent Standards.

Table 1. Samples and their representations.

\begin{tabular}{ccc}
\hline S/N & Sample Label & Description \\
\hline 1 & Sample 0 & Blank Sample for Calibration \\
2 & Standard 1 & First Standard Sample of Known Concentration \\
3 & Standard 2 & Second Standard Sample of known concentration \\
4 & Standard 3 & Third Standard Sample of known concentration \\
5 & Standard 4 & Fourth Standard Sample of known concentration \\
6 & Standard 5 & Fifth Standard Sample of known concentration \\
7 & WTPI & Wastewater Treatment Plant Inlet \\
8 & WTPAWW & Wastewater Treatment Plant Aerated Wastewater \\
9 & FLL & Fresh Landfill Leachate \\
10 & FHKG & Female Hostel Kitchen Greywater \\
11 & AUTOSWW & Auto-Service Workshop Wastewater \\
12 & CWW & Central Workshop Wastewater \\
13 & FSSE & Foundry Settled Sewage Effluent \\
14 & CLW & Commercial Laundry Wastewater \\
15 & FRIW & Foundry Raw Inlet Wastewater \\
16 & PGGHW & Postgraduate Girls' Hostel Wastewater \\
17 & SLL & Stale Landfill Leachate \\
18 & BHW & Boys' Hostel Wastewater \\
\hline
\end{tabular}

Table 2. The sample and instrumentation details.

\begin{tabular}{|c|c|c|c|c|c|c|c|}
\hline \multirow[b]{2}{*}{$\mathrm{S} / \mathrm{N}$} & \multirow[b]{2}{*}{ Element } & \multicolumn{3}{|c|}{ Instrument Parameters } & \multicolumn{3}{|c|}{ Sample Measurement Parameters } \\
\hline & & $\begin{array}{l}\text { Lamp current } \\
(\mathrm{mA})\end{array}$ & $\begin{array}{l}\text { Wavelength } \\
\text { (nm) }\end{array}$ & $\begin{array}{l}\text { Slit width } \\
\text { (nm) }\end{array}$ & Measurement mode & Read time (s) & Replicates \\
\hline 1 & $\mathrm{Cu}$ & 3.00 & 327.40 & 0.50 & \multirow{8}{*}{ Integration } & \multirow{8}{*}{2.00} & \multirow{8}{*}{2} \\
\hline 2 & $\mathrm{~Pb}$ & 5.00 & 217.00 & 1.00 & & & \\
\hline 3 & $\mathrm{Mg}$ & 3.00 & 202.60 & 1.00 & & & \\
\hline 4 & $\mathrm{Cr}$ & 6.00 & 359.30 & 0.20 & & & \\
\hline 5 & $\mathrm{Ni}$ & 4.00 & 341.50 & 0.20 & & & \\
\hline 6 & $\mathrm{Zn}$ & 5.00 & 213.90 & 0.50 & & & \\
\hline 7 & $\mathrm{Mn}$ & 5.00 & 403.10 & 0.20 & & & \\
\hline 8 & $\mathrm{Cd}$ & 3.00 & 326.10 & 0.50 & & & \\
\hline
\end{tabular}

(highest concentration), and in the Central Workshop Wastewater (3.6 ppm). It's presence in both Auto-Service Wastewater and in the Stale Landfill Leachate samples is marginal and does not constitute pollution when compared with the Standards. The rest domestic wastewater samples do not have traces of Ni.

Zinc (Zn)_Pollution is recorded in decreasing order from samples of Auto-Service Workshop Wastewater, Stale Landfill Leachate, Postgraduate Girls Hostel Wastewater, Central Workshop Wastewater, Boys’ Hostel Wastewater, Auto-Service Workshop Wastewater, Wastewater Treatment Plant Inlet, Wastewater Treatment Plant Aerated Sewage, Female Hostel Kitchen Wastewater, Foundry Raw Inlet Wastewater, and to Foundry Set- 
Table 3. Concentration levels of trace elements in the samples compared with EPA Effluent Standards.

\begin{tabular}{|c|c|c|c|c|c|c|c|c|c|c|c|c|c|c|c|c|c|}
\hline \multirow[b]{2}{*}{$\mathrm{S} / \mathrm{N}$} & \multirow[b]{2}{*}{ Sample } & \multicolumn{16}{|c|}{ Average concentration of trace elements compared with the EPA Effluent Standards, EPAES } \\
\hline & & $\begin{array}{c}\mathrm{Cu} \\
\left(\times 10^{2}\right. \\
\mathrm{ppm})\end{array}$ & $\begin{array}{c}\text { EPA } \\
\text { ES }\end{array}$ & $\begin{array}{c}\mathrm{Pb} \\
\left(\times 10^{2}\right. \\
\mathrm{ppm})\end{array}$ & $\begin{array}{c}\text { EPA } \\
\text { ES }\end{array}$ & $\begin{array}{c}\mathrm{Mg} \\
\left(\times 10^{2}\right. \\
\mathrm{ppm})\end{array}$ & $\begin{array}{c}\text { EPA } \\
\text { ES }\end{array}$ & $\begin{array}{c}\mathrm{Cr} \\
\left(\times 10^{2}\right. \\
\mathrm{ppm})\end{array}$ & $\begin{array}{c}\text { EPA } \\
\text { ES }\end{array}$ & $\begin{array}{c}\mathrm{Ni} \\
\left(\times 10^{2}\right. \\
\mathrm{ppm})\end{array}$ & $\begin{array}{c}\text { EPA } \\
\text { ES }\end{array}$ & $\begin{array}{c}\mathrm{Zn} \\
\left(\times 10^{2}\right. \\
\mathrm{ppm})\end{array}$ & $\begin{array}{c}\text { EPA } \\
\text { ES }\end{array}$ & $\begin{array}{l}\mathrm{Mn} \\
\left(\times 10^{2}\right. \\
\mathrm{ppm})\end{array}$ & $\begin{array}{c}\text { EPA } \\
\text { ES }\end{array}$ & $\begin{array}{c}\mathrm{Cd} \\
\left(\times 10^{2}\right. \\
\mathrm{ppm})\end{array}$ & $\begin{array}{c}\text { EPA } \\
\text { ES }\end{array}$ \\
\hline 1 & $\begin{array}{c}\text { Blank } \\
\text { Sample }\end{array}$ & - & & - & & - & & - & & - & & - & & - & & - & \\
\hline 2 & Standard 1 & 2.00 & & 2.00 & & 5.00 & & 5.00 & & 5.00 & & 0.50 & & 5.00 & & 5.00 & \\
\hline 3 & Standard 2 & 4.00 & & 4.00 & & 10.00 & & 10.00 & & 10.00 & & 1.00 & & 10.00 & & 10.00 & \\
\hline 4 & Standard 3 & 6.00 & & 6.00 & & 15.00 & & 15.00 & & 15.00 & & 1.50 & & 15.00 & & 15.00 & \\
\hline 5 & Standard 4 & 8.00 & & 8.00 & & 20.00 & & 20.00 & & 20.00 & & 2.00 & & 20.00 & & 20.00 & \\
\hline 6 & Standard 5 & 10.00 & & 10.00 & & - & & - & & - & & - & & - & & - & \\
\hline 7 & WTPI & 0.046 & & 0.125 & & 0.284 & & ND & & ND & & 0.014 & & ND & & ND & \\
\hline 8 & WTPAWW & 0.013 & & 0.109 & & 0.309 & & ND & & ND & & 0.012 & & 0.023 & & 6.815 & \\
\hline $\begin{array}{c}9 \\
10\end{array}$ & $\begin{array}{c}\text { FLL } \\
\text { FHKG }\end{array}$ & $\begin{array}{c}\text { ND } \\
0.018\end{array}$ & 3.00 & $\begin{array}{c}0.259 \\
\text { ND }\end{array}$ & 1.00 & $\begin{array}{l}4.174 \\
0.229\end{array}$ & N/A & $\begin{array}{l}\text { ND } \\
\text { ND }\end{array}$ & 2.00 & $\begin{array}{l}\text { ND } \\
\text { ND }\end{array}$ & 1.00 & $\begin{array}{c}\text { ND } \\
0.011\end{array}$ & 5.00 & $\begin{array}{l}\text { ND } \\
\text { ND }\end{array}$ & 2.00 & $\begin{array}{l}9.433 \\
8.731\end{array}$ & 0.03 \\
\hline 11 & AUTOSWW & ND & & 0.116 & & 0.553 & & ND & & 0.003 & & 0.142 & & ND & & 13.898 & \\
\hline 12 & CWW & 0.038 & & 0.082 & & 0.334 & & 0.089 & & 0.036 & & 0.034 & & ND & & ND & \\
\hline 13 & FSSE & 0.031 & & ND & & 0.281 & & 0.349 & & ND & & 0.005 & & ND & & ND & \\
\hline 14 & CLW & 0.024 & & 0.144 & & 0.220 & & 0.156 & & ND & & ND & & ND & & ND & \\
\hline 15 & FRIW & ND & & 0.076 & & 0.132 & & ND & & 0.056 & & 0.007 & & ND & & ND & \\
\hline 16 & PGGHW & 0.030 & & 0.120 & & 0.282 & & ND & & ND & & 0.053 & & ND & & ND & \\
\hline 17 & SLL & 0.267 & & 0.026 & & 8.216 & & ND & & 0.009 & & 0.116 & & ND & & 18.564 & \\
\hline 18 & BHW & 0.004 & & 0.067 & & 0.304 & & ND & & ND & & 0.023 & & ND & & ND & \\
\hline
\end{tabular}

Notes: N/A = Not Available; ND = Not Detected.

tled Sludge Effluent. Zn is not detected in both Fresh Landfill Leachate and the Commercial Laundry Wastewater.

Manganese (Mn) - The only sample containing $\mathrm{Mn}$ is the Aerated Sewage in the Wastewater Treatment Plant $(2.3 \mathrm{ppm})$, a value just slightly beyond the recommended safe EPA effluent of $2.0 \mathrm{ppm}$. This has the capability of reacting with oxygen to form Manganese Oxide.

Cadmium (Cd) - Five samples have heavy Pollution from Cd while the rest do not possess its traces. Compared with the EPA standards, the Stale Landfill Leachate causes the most Cd pollution of about $1856.4 \mathrm{ppm}$, followed by the Auto-Service Workshop Wastewater (1389.8 ppm). The other samples causing Cd pollution as compared with the Standards are Fresh Landfill Leachate (943.3 ppm), Female Hostel Kitchen Wastes (873.1 ppm) and Aerated Wastewater of the Treatment Plant (681.5 ppm).

\section{Conclusion}

The study has looked into the possible pollution arising from the concentration of trace metals in the twelve selected wastewater samples in Nitte Community, Udupi District, India. The measured heavy metals; $\mathrm{Cu}, \mathrm{Pb}, \mathrm{Mg}$, $\mathrm{Cr}, \mathrm{Ni}, \mathrm{Zn}, \mathrm{Mn}$ and $\mathrm{Cd}$ all constituted pollution when compared with the EPA Effluent Standards. The heaviest concentration occurred in Cd with as high as $1856.4 \mathrm{ppm}$ as found in the Stale Landfill Leachate sample, while the least contaminating metal in the samples is Manganese which was detected in only Aerated Wastewater Treatment Plant sample (2.3 ppm). This study is therefore recommending Electro-coagulation treatment method for metals in high concentration like $\mathrm{Cd}, \mathrm{Pb}, \mathrm{Mg}$ and $\mathrm{Cu}$, while those with lesser concentration such as $\mathrm{Mn}, \mathrm{Cr}, \mathrm{Ni}$ and $\mathrm{Zn}$ are to be treated with chemical precipitation.

\section{Acknowledgements}

The Authors are grateful to the Authorities of both NMAM Institute of Technology, Nitte 574-110, India and Ladoke Akintola University of Technology, P.M.B. 4000, Ogbomoso, Nigeria for all-round supports leading to the success of this research work. 


\section{References}

[1] Chang, A.C. and Page, A.L. (1977) Trace Elements in Wastewater. California Agriculture, 32-33.

[2] Haijian, B., Yanhong, W., Zhaobin, S. and Shuchun, Y. (2011) Historical Trends of Heavy Metal Contamination and Their Sources in Lacustrine Sediment from Xijiu Lake, Taihu Lake Catchment, China. Journal of Environmental Sciences, 23, 1671-1678. http://dx.doi.org/10.1016/S1001-0742(10)60593-1

[3] Hui, K.S., Chao, C.Y.H. and Kot, S.C. (2005) Removal of Mixed Heavy Metal Ions in Wastewater by Zeolite 4A and Residual Products from Recycled Coal Fly Ash. Journal of Hazardous Materials, 127, 89-101. http://dx.doi.org/10.1016/j.jhazmat.2005.06.027

[4] Karvelas, M., Katsoyiannis, A. and Samara, C. (2003) Occurrence and Fate of Heavy Metals in the Wastewater Treatment Process. Chemosphere, 53, 1201-1210. http://dx.doi.org/10.1016/S0045-6535(03)00591-5

[5] Ahluwalia, S.S. and Goyal, D. (2007) Microbial and Plant Derived Biomass for Removal of Heavy Metals from Wastewater. Bioresource Technology, 98, 98-2243. http://dx.doi.org/10.1016/j.biortech.2005.12.006

[6] European Commission (2002) DG ENV. E3, Project ENV.E3/ETU/2000/0058, Heavy Metals in Waste. Final Report, February 2002.

[7] Rippey, B., Rose, N., Yang, H., Harrad, S., Robson, M. and Travers, S. (2008) An Assessment of Toxicity in Profundal Lake Sediment Due to Deposition of Heavy Metals and Persistent Organic Pollutants from the Atmosphere. Environment International, 34, 345-356. http://dx.doi.org/10.1016/j.envint.2007.03.006

[8] Atici, T., Ahiska, S., Altindag, A. and Aydin, D. (2008) Ecological Effects of Some Heavy Metals (Cd, Pb, Hg, Cr) Pollution of Phytoplanktonic Algae and Zooplanktonic Organisms in Saryyar Dam Reservoir in Turkey. African Journal of Biotechnology, 7, 1972-1977.

[9] Ley-Quinonez, Q.C., Zavala N.A.A., Espinosa-Carreon, T.L., Peckham, H., Marquez-Herrera, C. and Campos-Villegas, L. (2011) Baseline Heavy Metals and Metalloid Values in Blood of Loggerhead Turtles (Caretta caretta) from BajaCalifornia Sur, Mexico. Marine Pollution Bulletin, 62, 1979-1983. http://dx.doi.org/10.1016/j.marpolbul.2011.06.022

[10] Shi, B., Zhaoyu, H. and Lu, Z. (2008) Environmental Pollution and Human Health. China Environmental Press, Beijing.

[11] Bradl, H. (2005) Heavy Metals in the Environment: Origin, Interaction and Remediation. Elsevier/Academic Press, London.

[12] Prabu, P.C. (2009) Impact of Heavy Metal Contamination of Akaki River of Ethiopia on Soil and Metal Toxicity on Cultivated Vegetable Crops. Electronic Journal of Environmental, Agricultural and Food Chemistry, 8, 818-827.

[13] Asli, B., Nil, O. and Suleyman, A. (2013) Determination of Trace Metals in Waste Water and Their Removal Processes. 147-150. http://dx.doi.org/10.5772/52025

[14] Ojoawo, S.O. and Udayakumar, G. (2014) An investigation on Trace Metals as Pollution indices in the Municipal Wastewater of Nitte, Udupi District, India. Proceedings of International Conference on Advances in Engineering and Technology, Goa, April 2014, 29-33. 
Scientific Research Publishing (SCIRP) is one of the largest Open Access journal publishers. It is currently publishing more than 200 open access, online, peer-reviewed journals covering a wide range of academic disciplines. SCIRP serves the worldwide academic communities and contributes to the progress and application of science with its publication.

Other selected journals from SCIRP are listed as below. Submit your manuscript to us via either submit@scirp.org or Online Submission Portal.
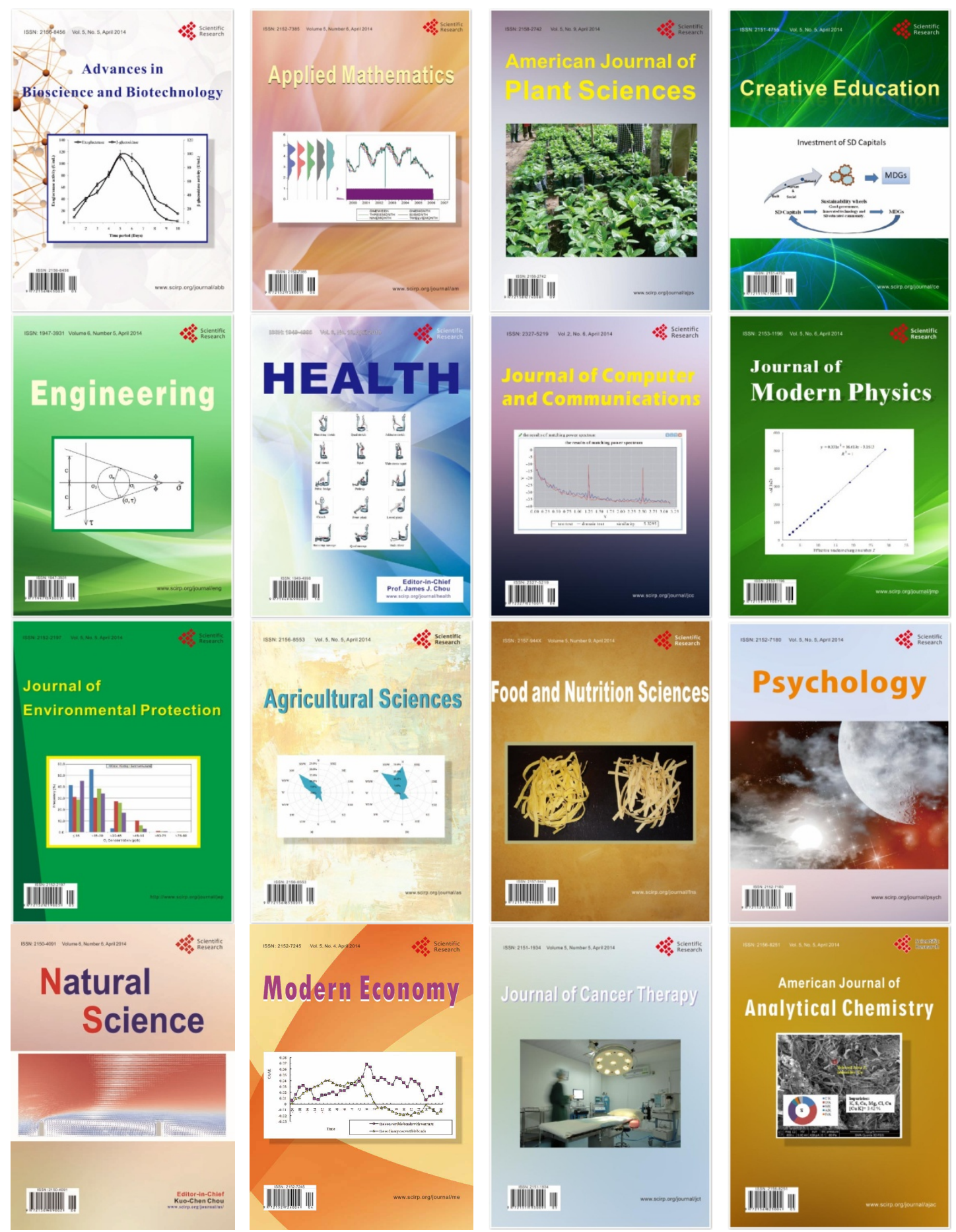